Kredo 4 (2020)
KREDO: Jurnal Ilmiah Bahasa dan Sastra
Terakreditasi Sinta 4 berdasarkan Keputusan Direktorat
Jenderal Penguatan Riset dan Pengembangan,
Kementerian Riset, Teknologi dan Pendidikan Tinggi
Republik Indonesia
Nomor: 23/E/KPT/2019. 08 Agustus 2019
https://jurnal.umk.ac.id/index.php/kredo/index

\title{
ESKALASI BUDAYA MENULIS FIKSI PADA ANAK USIA 7-11 TAHUN
}

\author{
Chris Setiawan Adi Putra ${ }^{1}$, Aninditya Sri Nugraheni ${ }^{2}$ \\ adpchris0@gmail.com
}

UIN Sunan Kalijaga Yogyakarta. Indonesia

Info Artikel
Sejarah Artikel
Diterima
17 Juni 2020
Disetujui
21 September 2020
Dipublikasikan
28 Oktober 2020
Keywords writing,
Escalation, elementary
fiction,
school. Kunci
Kata Kunc
Eskalasi, menulis,
fiksi, sekolah dasar

Info Artikel : :

The purpose of this research is to promote a person's writing culture since they were in elementary school aged 7-11 years, so that when someone takes the world of education in a tertiary institution they already have writing skills. The method used in this research is a descriptive qualitative method which is arranged with a narrative based on the data that has been obtained from the research that has been done. In addition, observation is also a research method in observing student behavior in expressing ideas through writing which is a stark contrast to their speaking ability. The data in this study were obtained by utilizing a questionnaire that had been filled in by students about the importance of the culture of writing fiction since they were in elementary school. The results of the study were in the form of student arguments about the importance of introducing writing culture since elementary school, which had been introduced to personal experiences entitled fiction. This study reveals that the difficulties experienced by students in writing are still widely found, this is due to the lack of reading frequency and the assumption that writing is difficult to apply so that many of them choose to speak directly instead of writing. Abstrak
Tujuan penelitian ini untuk menggalakkan budaya menulis seseorang sejak berada di sekolah
dasar usia 7-11 tahun, sehingga ketika seseorang itu menempuh dunia pendidikan di Perguruan
Tinggi ia telah memiliki keterampilan dalam hal tulis-menulis. Metode yang digunakan dalam
penelitian ini berupa metode kualitatif deskriptif yang disusun dengan sebuah narasi berdasarkan
data-data yang telah diperoleh dari penelitian yang telah dilakukan. Selain itu, observasi juga
menjadi sebuah metode penelitian dalam mengamati perilaku mahasiswa dalam mengungkapkan
gagasan melalui tulisan yang sangat kontras jika dibandingkan dengan kemampuan berbicaranya.
Data-data dalam penelitian ini diperoleh dengan memanfaatkan kuisioner yang telah diisi oleh
mahasiswa tentang pentingnya budaya menulis fiksi sejak berada dalam sekolah dasar. Hasil
penelitian berupa argumen mahasiswa tentang pentingnya pengenalan budaya menulis sejak sekolah
dasar yang telah dikenalkan karangan pengalaman pribadi bertajuk fiksi. Penelitian ini mengungkap
bahwa kesulitan-kesulitan yang dialami oleh mahasiswa dalam menulis masih banyak ditemukan,
hal itu terjadi karena minimnya frekuensi membaca dan anggapan bahwa menulis itu sulit
diterapkan sehingga mereka banyak yang memilih berbicara langsung dari pada menulis.

\section{PENDAHULUAN}

\section{Menurut Amanda}

$(2016: 831)$

Literasi adalah salah satu kajian pokok yang selalu diperbincangkan dalam ranah Pelajaran Bahasa Indonesia, terutama dalam hal menulis dan membaca. Menulis sendiri pada dasarnya merupakan kemampuan yang dimiliki oleh seseorang dalam memanifestasikan sebuah keterampilan berbahasa yang paling akhir, yaitu setelah kemampuan membaca, mendengar dan berbicara. Menulis sejatinya dapat diartikan sebagai kegiatan dalam mengeskpresikan sebuah gagasan, ide ataupun sebuah perasaan kedalam bentuk bait-bait kalimat yang padu. Setiap tulisan yang ditulis oleh penulis pada dasarnya memiliki sebuah tujuan, terutama agar pembaca dapat memperoleh informasi dari bacaannya.

Dengan menulis kita tidak akan pernah takut untuk lenyap dalam kehidupan dan sejarah hal itu tentu menjadi sesuatu yang sangat penting, apalagi jika tulisan yang kita buat merupakan karya yang penuh dengan 


\begin{tabular}{|c|c|c|} 
Kredo 4 (2020) \\
KREDO: Jurnal Ilmiah Bahasa dan Sastra \\
Terakreditasi Sinta 4 berdasarkan Keputusan Direktorat \\
Jenderal Penguatan Riset dan Pengembangan, \\
Kementerian Riset, Teknologi dan Pendidikan Tinggi \\
Republik Indonesia \\
Nomor: 23/E/KPT/2019. 08 Agustus 2019 \\
https://jurnal.umk.ac.id/index.php/kredo/index
\end{tabular}

manfaat. Misalnya, dapat menjadi sumber ilmu dan inspirasi bagi pembaca. Amal dalam menebar kebaikan itu tidak akan pernah putus, seperti halnya amal jariyah dalam agama islam yang menerangkan bahwa sebuah perbuatan baik yang pernah dilakukan semasa hidup, pahala yang kita lakukan tersebut akan terus mengalir sepanjang masa bahkan walaupun ia telah meninggal pun amalannya akan terus mengalir bak sungai kehidupan

Menulis merupakan kegiatan untuk mengekspresikan diri, bahkan bisa dikatakan sebagai wujud tingkah, tindakan, sifat dan sikap dari penulis yang terefleksikan dalam bentuk tulis. Penulisan sebuah cerita fiksi merupakan karya imajinatif yang dilakukan oleh seseorang untuk menuangkan ide dan gagasannya. Karangan ini bersifat tidak nyata karena dibuat semata-mata untuk menggambarkan keadaan yang sedang penulis imajinasikan, walaupun terkadang dalam bentuk tulisan tergolong cerita yang benar-benar terjadi di muka bumi ini, namun penulisan fiksi telah dimodivikasi sedemikian rupa supaya sulit diterima akan rasionalitasnya.

Amanda (2016:832) juga menjelaskan bahwa fiksi pada dasarnya bertujuan untuk membuat sesuatu yang tidak nyata menjadi kisah yang seolaholah terjadi di dalam kehidupan ini, atau bisa juga dikatakan sebagai pemberian alternatif untuk menceritakan suatu peristiwa yang dapat ditafsirkan dalam kehidupan atau menceritakan sesuatu bukan sebagaiamana yang sungguh benar-benar terjadi diatas muka bumi ini, tetapi sebagaimana yang dibayangkan dan dikhayalkan oleh penulis. Jadi, penulisan cerita fiksi merupakan sebuah karya yang tercipta atas dasar rekayasa manusia yang berawal dari imajinasi penciptanya.

Dalam penulisan fiksi diperlukan imajinasi dari penulis, tidak seperti halnya penulisan karya ilmiah seperti essay dan artikel yang harus menuliskan sebuah produk tulisan berdasarkan datadata ataupun refrensi untuk dijadikan dasar tulisan. Meskipun penulisan fiksi bersifat bebas namun pola pikir seseorang juga berbeda, hal itu menimbulkan keanekaragaman genre tulisan yang disesuaikan dengan usia dan tingkat kematanganya. Seperti halnya pada anak yang berusia dibawah 12 tahun tengah berada dalam masa perkembangan intelektual tahap operasional kongkret yang pastinya menimbulkan identitas suatu tulisan. Dari sinilah dapat kita ketahui bersama jika gaya penulisan sebuah cerita juga dipengaruhi oleh umur, untuk itulah seorang pendidik juga harus mengklarifikasikan jenis tulisan ataupun bacaan kepada peserta didik.

Adanya pembelajaran cerita fiksi pada anak usia 7-11 tahun menjadi tonggak awal dalam proses mengembangkan imajinasi ataupun bentuk ekspresi diri kedalam tulisan. Jika sedari sekolah dasar budaya menulis sudah diterapkan harapan untuk tahap proses dewasanya yaitu menjadi penulis yang lebih handal dengan beberapa imajinasi yang baru yang tidak pernah dibayangkan oleh manusia pada umumnya. Seperti halnya apa yang dilakukan oleh Tere Liye, ia berhasil membuat karya salah satunya adalah novel Rembulan Tenggelam di Wajahmu yang diterbitkan tahun 2009 tentu juga 


\begin{tabular}{|c|c|c|} 
Kredo 4 (2020) \\
KREDO: Jurnal Ilmiah Bahasa dan Sastra \\
Terakreditasi Sinta 4 berdasarkan Keputusan Direktorat \\
Jenderal Penguatan Riset dan Pengembangan, \\
Kementerian Riset, Teknologi dan Pendidikan Tinggi \\
Republik Indonesia \\
Nomor: 23/E/KPT/2019. 08 Agustus 2019 \\
https://jurnal.umk.ac.id/index.php/kredo/index
\end{tabular}

melalui tahapan yang panjang. Beliau memulai karir pada dunia tulis menulis semenjak duduk di bangku sekolah dasar, pada waktu itu ia memulai dengan mengirimkan beberapa cerita pendek ke majalah Bobo dan Tomtom meskipun pada akhirnya karya tersebut tidak pernah dimuat, namun berkat ketekunan yang ia miliki dan beberapa pengalaman menulis. Pada waktu SMP dan SMA beberapa karyanya sudah mulai berhasil dimuat dibeberapa media seperti di majalah maupun di Koran bahkan karyakaryanya berlanjut di dunia novel yang saat ini dapat kita ketahui betapa menakjubnya karya-karya tersebut.

Tabel 1: Penulis Indonesia yang memulai

\begin{tabular}{|c|c|c|}
\hline Penulis & Karir Pertama & Karya \\
\hline Raditya Dika & $\begin{array}{l}\text { Pertama kali } \\
\text { menulis sejak } \\
\text { sekolah dasar. } \\
\text { Memulai } \\
\text { karya dengan } \\
\text { menulis diary } \\
\text { Tazmania } \\
\text { Devil. } \\
\text { (Dikutip dari } \\
\text { tabloidbintan } \\
\text { g.com } \\
\text { terbitan } 14 \\
\text { Agustus } \\
\text { 2016) }\end{array}$ & $\begin{array}{l}\text {-Kambing } \\
\text { Jantan, } \\
\text {-Cinta } \\
\text { brontosaurus, } \\
\text {-Marmut } \\
\text { merah jambu, } \\
\text {-Manusia } \\
\text { setengah } \\
\text { salmon, } \\
\text {-Koala } \\
\text { kumal. } \\
\text { Dll. }\end{array}$ \\
\hline Boy Candra & $\begin{array}{l}\text { Memiliki } \\
\text { hobby } \\
\text { menulis sejak } \\
\text { SD, namun } \\
\text { baru berkarir } \\
\text { di dunia tulis } \\
\text { pada } 2011 . \\
\text { (Dikutip dari } \\
\text { lpmmissi.com } \\
\text { terbitan } 16 \\
\text { Desember } \\
\text { 2019) }\end{array}$ & $\begin{array}{l}\text {-Sebuah } \\
\text { usaha } \\
\text { melupakan, } \\
\text {-Origami } \\
\text { hati, } \\
\text {-Setelah } \\
\text { hujan reda, } \\
\text { Dll. }\end{array}$ \\
\hline Asma Nadia & $\begin{array}{l}\text { Memulai } \\
\text { menulis } \\
\text { cerpen ketika } \\
\text { ia duduk } \\
\text { dibangku } \\
\text { SMP } \\
\text { (Dikutip dari } \\
\text { biografiku.co }\end{array}$ & $\begin{array}{l}\text {-Surga yang } \\
\text { tidak } \\
\text { dirindukan, } \\
\text {-Rumah } \\
\text { tanpa } \\
\text { jendela, } \\
\text { Dll. }\end{array}$ \\
\hline
\end{tabular}

\begin{tabular}{|c|c|c|}
\hline & $\begin{array}{l}m \text { terbitan } 8 \\
\text { maret 2017) }\end{array}$ & \\
\hline Andrea Hirata & $\begin{array}{l}\text { Memulai } \\
\text { dunia tulis- } \\
\text { menulis } \\
\text { ketika kelas } 3 \\
\text { SD, yaitu } \\
\text { ketika ia } \\
\text { melihat } \\
\text { perjuangan } \\
\text { seorang guru } \\
\text { yang begitu } \\
\text { mulia dalam } \\
\text { mendidik. } \\
\text { (Dikutip dari } \\
\text { Kompasiana } \\
\text { terbitan 13 } \\
\text { Agustus } \\
\text { 2013) }\end{array}$ & $\begin{array}{l}\text {-Laskar } \\
\text { Pelangi, } \\
\text {-Sang } \\
\text { Pemimpi, } \\
\text {-Cinta di } \\
\text { Dalam Gelas, } \\
\text {-Ayah, } \\
\text {-Guru Aini, } \\
\text {-Orang-orang } \\
\text { Biasa. } \\
\text { Dll. }\end{array}$ \\
\hline $\begin{array}{l}\text { Eriska } \\
\text { Febriani }\end{array}$ & $\begin{array}{l}\text { Menulis } \\
\text { ketika SMP, } \\
\text { waktu itu ia } \\
\text { mendapat } \\
\text { motivasi dari } \\
\text { beberapa } \\
\text { temannya } \\
\text { berkat tulisan } \\
\text { yang ia } \\
\text { berikan } \\
\text { kepada } \\
\text { mereka. } \\
\text { (Dikutip dari } \\
\text { Gramedia.co } \\
\text { m terbitan } 20 \\
\text { September } \\
\text { 2018) }\end{array}$ & $\begin{array}{l}\text {-Dear } \\
\text { Nathan, } \\
\text {-Hello Salma }\end{array}$ \\
\hline
\end{tabular}

Eskalasi budaya menulis fiksi pada dasarnya tidak hanya diperuntukan untuk meningkatkan budaya menulis saja, namun juga untuk mematahkan label minat dunia literasi yang semakin menurun, terutama dibidang tulismenulis. Namun, seseorang tidak akan hanya sebatas menjadi konsumen buku saja, tetapi juga menjadi produsen yang dapat mewarnai ramainya keanekaragaman dunia literasi

Seiring bertambahnya usia, manusia tidak akan pernah lepas dari sebuah istilah yang disebut perubahan. Tidak mungkin jika manusia hidup selamanya, karena ajal pasti akan menentukan kapan 


Kredo 4 (2020)
KREDO: Jurnal Ilmiah Bahasa dan Sastra
Terakreditasi Sinta 4 berdasarkan Keputusan Direktorat
Jenderal Penguatan Riset dan Pengembangan,
Kementerian Riset, Teknologi dan Pendidikan Tinggi
Republik Indonesia
Nomor: 23/E/KPT/2019. 08 Agustus 2019
https://jurnal.umk.ac.id/index.php/kredo/index

waktu itu akan berakhir. Akan tetapi, dalam sebuah kehidupan pasti ada jejak langkah yang ditinggalkan, seperti halnya sebuah karya yang pernah dibuat seseorang, tentu membuat nama seseorang terus abadi dan tak pernah terlupakan oleh sejarah. Penulis menyadari bahwa semesta terus berjalan seperti biasanya, selalu ada pembaharuan disetiap generasi. Bisa kita lihat pada Pramodya Ananta Tour semasa hidup, beliau aktif dalam pembuatan sebuah karya tulis yang sangat fenomenal pada masanya, dan kini ketika beliau telah tiada namanya masih saja disebut oleh manusia dalam generasi yang berbeda bahkan karya tulisnya kini telah diangkat kedalam layar lebar untuk dinikmati di layar kaca.

Dari masa ke masa, selalu ada sosok public figure yang sangat terkenal dengan prestasi kepenulisanya mulai dari Andrea Hirata, Tere Liye, Boy Chandra, Rintik Sedu dan yang sedang terkenalnya baru-baru ini adalah sosok penulis yang sekaligus menjadi musisi Indonesia, yaitu Fiersa Besari. Hal itu menjadi penting, mengingat dunia kepenulisan sudah dikenalkan di sekolah dasar terutama untuk mencari bibit-bibit baru yang lebih berkualitas dan menjadi penulis yang handal dimasa depan. Eskalasi menulis fiksi pada anak usia 711 tahun hadir untuk mempersiapkan generasi selanjutnya agar memiliki keterampilan dalam kegiatan tulismenulis.

\section{KAJIAN TEORI}

Eskalasi budaya menulis fiksi pada anak usia 7-11 tahun merupakan penelitian yang digariskan untuk meningkatkan kemapuan menulis sejak dini. Fiksi sendiri adalah karya yang tepat untuk dijadikan bahan penulisan karya pada usia 7-11 tahun karena pada usia tersebut anak sedang menempuh masa perkembangan intelektual tahap operasional konkret. Vero Sudiati dan A. Widyatama (1995:50) berpendapat bahwa menulis cerita fiksi merupakan gambaran tindak penciptaan ilahi sendiri, yang menciptakan sesuatu dari tiada menjadi ada. Artinya, apa yang dituliskan oleh penulis berasal dari apa yang dibayangkan dan dikhayalkan olehnya. Dengan begitu, menulis cerita fiksi menjadi tonggak awal bagi siswa untuk mengetahui bagaimana cara mengembangkan khayalan ataupun imajinasinya kedalam bentuk tulisan.

Cerita fiksi merupakan bagian dari sastra, sastra yang tepat bagi usia 7-11 tahun adalah sastra anak. Menurut Burham Nurgiantoro (2004:107) sastra anak adalah sastra yang berbicara tentang apa saja yang menyangkut masalah kehidupan ini sehingga mampu memberikan informasi dan pemahaman yang lebih baik tentang kehidupan itu sendiri kepada anak. Fiksi yang termasuk genre prosa jika kita lihat isi dari bacaannya maka kita akan menemukan beberapa bentuk ungkapan imajinatif/khayalan dari penulisnya. Cerita fiksi anak terbagi kedalam beberapa jenis, yaitu fiksi ilmiah, sejarah, formula dan cerita fantasi. Sedangkan, yang disebut dengan cerita Non-Fiksi sendiri merupakan sebuah karangan yang ditulis berdasarkan realita serta kebenaran dari sebuah datadata yang ditulis dapat dipertanggung jawabkan akan keyakinannya. Cerita ini juga beraneka ragam macamnya, sebagai 


Kredo 4 (2020)
KREDO: Jurnal Ilmiah Bahasa dan Sastra
Terakreditasi Sinta 4 berdasarkan Keputusan Direktorat
Jenderal Penguatan Riset dan Pengembangan,
Kementerian Riset, Teknologi dan Pendidikan Tinggi
Republik Indonesia
Nomor: 23/E/KPT/2019. 08 Agustus 2019
https://jurnal.umk.ac.id/index.php/kredo/index

contoh dari jenis karangan ini adalah biografi yang memuat cerita kehidupan seseorang sehingga pembacanya dapat memperoleh informasi dari sebuah bacaan bahkan menjadi inspirasi tentang kehebatan-kehebatan sosok yang diceritakan dalam biografi itu sendiri.

Sastra, menurut Lukens (1999:10), menawarkan dua hal dalam penyajiannya. Hal itu selayaknya tidak boleh luput dalam penciptannnya karena penyajian sastra yang ditawarkan juga harus memenuhi unsur kesenangan dan pemahaman bagi penikmatnya. Lukens (1999:4) juga menegaskan bahwa sastra memberikan hiburan dan memuaskan pembaca, sehingga seolah-olah pembaca dapat terbawa langsung dari cerita yang dibacanya. Sejarah lahirnya sastra anak belum diketahui secara pasti bagaimana asal muasalnya dan kapan karya itu diciptakan, akan tetapi satu hal yang perlu untuk kita ketahui bersama adalah sastra anak sendiri lahir berawal dari mimpi, harapan dan suka duka yang asalnya dari kehidupan nyata sampai pada cerita rekayasa manusia. Pada mulanya cerita itu lahir secara turuntemurun dan hanya bersumber pada pada ucapan lisan dari mulut ke mulut, bahkan sering digunakan oleh orang dewasa sebagai dongeng sebelum tidur pada anak-anaknya.

Zaman yang semakin berkembang membuat manusia ingin menciptakan inovasi baru, termasuk pada dunia sastra yang mengalami perombakan. Ceritacerita yang pada mulanya hanya diucapkan secara lisan, semakin hari mulai dituliskan kedalam bentuk buku yang kini dapat kita nikmati untuk menjadi buku bacaan terutama untuk anak-anak sendiri. Tidak berhenti pada titik itu saja, sastra anak menunjukkan kesuburan pada masanya. Pada setiap jengkal kehidupan sastra anak mulai menunjukkan beberapa karakter, salah satunya adalah adanya buku yang menjelaskan perihal keagamaan maupun nilai moral yang mampu membentuk karakter dari anak itu sendiri. Perkembangan dunia sastra anak yang mengalami beberapa perkembangan seperti evousi dalam bentuk lisan menjadi tulisan, di Indonesia sendiri masih sulit untuk ditemukan beberapa karya-karya tersebut. Minimnya bacaan sastra anak yang kurang memadai membuat anak-anak kesulitan dalam menemukan jenis bacaan yang sesuai dengan tahap perkembangannya kalaupun ada tidak sedikit diantara mereka yang mengadaptasi buku-buku dari luar negeri yang diterjemahkan kedalam bahasa Indonesia yang banyak mengedepankan pendidikan dan pengajaran moral. Winch (1991:19) menegaskan bahwa buku anak yang baik mengantarkan dan berangkat dari kacamata anak. Selain itu, Huck, dkk. (1987:6) juga menekankan sastra anak, adalah buku yang menempatkan sudut pandang anak sebagai pusat penceritaan.

Sulitnya penemuan buku-buku sastra anak yang dapat dijumpai di negeri ini tentu menjadi pekerjaan rumah yang harus kita hadapi bersama, sehingga anak-anak dapat membaca beberapa referensi buku yang selaras dengan pola pikirnya atau bisa dikatakan membaca sesuai dengan batas umur yang ditentukan juga supaya tidak membaca bacaan orang dewasa yang didalamnya terdapat beberapa kisah romansa. Minimnya penulis-penulis yang terjun pada bidang sastra anak sendiri juga 


Kredo 4 (2020)
KREDO: Jurnal Ilmiah Bahasa dan Sastra
Terakreditasi Sinta 4 berdasarkan Keputusan Direktorat
Jenderal Penguatan Riset dan Pengembangan,
Kementerian Riset, Teknologi dan Pendidikan Tinggi
Republik Indonesia
Nomor: 23/E/KPT/2019. 08 Agustus 2019
https://jurnal.umk.ac.id/index.php/kredo/index

menjadi penyebab dari terbatasnya sumber bacaan sastra anak di Indonesia, padahal sebenarnya sastra anak memiliki kontribusi yang sangat besar dalam dunia sastra itu sendiri. Adapun kontribusi tersebut dapat berupa penambah matangnya perkembangan emosional anak, kecerdasan, imajinasi, kesadaran akan jiwa social dan pembangunan kreatifitas untuk membangun sumber daya manusia penerus generasi bangsa yang unggul sejak dini.

Menurut Burham Nurguyanto (2004:108) sastra anak juga merupakan bagian terpenting dalam sastra, tujuan adanya sastra anak berupa pengetahuan dan pemahaman yang lebih baik tentang kehidupan ataupun dalam menawarkan berbagai motivasi untuk membuat pembaca tertarik pada tingkat lanjut identifikasi. Apalagi jika pembacanya adalah anak-anak yang dunia fantasinya sedang berkembang dan dapat menerima segala macam cerita apakah masuk akal atau tidak, mereka akan sangat tertarik dengan dunia itu karena sastra pada dasarnya dikemas dengan bahasa yang menarik

Anak usia 7-11 tahun adalah usia sekolah dasar. Jika kita amati, usia tersebut adalah usia pertumbuhan dan perkembangan. Zulela (2013:53) menegaskan bahwa usia tersebut merupakan tahap perkembangan intelektual tahap operasional konkret dimana anak dapat mengembangkan imajinasi dari masa lalu dan masa depan sehingga akan sesuai jika anak seusia mereka dikenalkan dengan tulisan cerita fiksi.

88 | Jurnal Kredo Vol. 4 No. 1 Oktober 2020

\section{METODE PENELITIAN}

\section{Jenis Penelitian}

Setiap manusia tentu memiliki sebuah hasrat untuk menjadi pribadi yang sempurna, meskipun pada dasarnya kesempurnaan hanya dimilik tuhan semata. Kesempurnaan itu dapat juga diinginkan bahkan untuk diimplementasi-kan dalam sebuah karya yang manusia ciptakan, termasuk adanya penelitian ini. Beberapa usaha telah dilakukan, termasuk menentukan metodologi penelitian yang tepat. Penelitian ini menggunakan pendekatan kualitatif deskriptif yang didukung dengan beberapa pengamatan yang telah dilakukan guna untuk mengetahui seberapa pentingkah budaya menulis itu harus dilakukan sejak jauh-jauh hari, terutama semenjak anak-anak berada pada usia 7-11 tahun.

Penelitian ini dipaparkan sesuai dengan keadaan ataupun fenomena yang terjadi di masyarakat baru-baru ini dan berdasarkan fakta-fakta yang diperoleh di dunia nyata. Selain itu, harapan adanya penelitian ini juga mampu mendorong akademisi untuk terus menggiatkan "Eskalasi Budaya Menulis Sejak Dini" dengan begitu beberapa dampak positif akan dirasakan untuk kemaslahatan umat manusia terutama di Indonesia sendiri yang pertumbuhan dunia literasinya sedang patah.

2. Proses Penelitian

Penelitian ini dilakukan pada 15 Mei 2020 dengan memanfaatkan media digital seperti Google Form untuk memperoleh data-data penelitian. Google Form menjadi sumber utama pada pembahasan penelitian ini, meskipun beberapa pengamatan juga 


\begin{tabular}{|c|c|c|} 
Kredo 4 (2020) \\
KREDO: Jurnal Ilmiah Bahasa dan Sastra \\
Terakreditasi Sinta 4 berdasarkan Keputusan Direktorat \\
Jenderal Penguatan Riset dan Pengembangan, \\
Kementerian Riset, Teknologi dan Pendidikan Tinggi \\
Republik Indonesia \\
Nomor: 23/E/KPT/2019. 08 Agustus 2019 \\
https://jurnal.umk.ac.id/index.php/kredo/index
\end{tabular}

telah dilakukan jauh-jauh hari semenjak penulis untuk pertama kalinya menempuh dunia perkuliahan pada tahun 2019, dari sanalah dapat diketahui tentang kemampuan keterampilan mahasiswa dalam membuat sebuah tulisan seperti pembuatan makalah.

Sebuah penelitian tentunya memiliki objek, karena dari sanalah penelitian dapat membuahkan sebuah hasil yang ingin dicapai. Objek utama dari penelitian ini adalah mahasiswa, meskipun tujuan utamanya untuk meningkatkan budaya menulis di Sekolah Dasar. Beberapa argument akan banyak dijumpai, mengingat budaya menulis itu memang sudah seharusnya dilakukan sejak jauh-jauh hari, untuk itulah disini semua pihak memiliki sebuah harapan untuk kemajuan literasi di Indonesia pada generasi emas yang akan datang karena yang menjadi tumpuannya adalah anak-anak usia Sekolah Dasar.

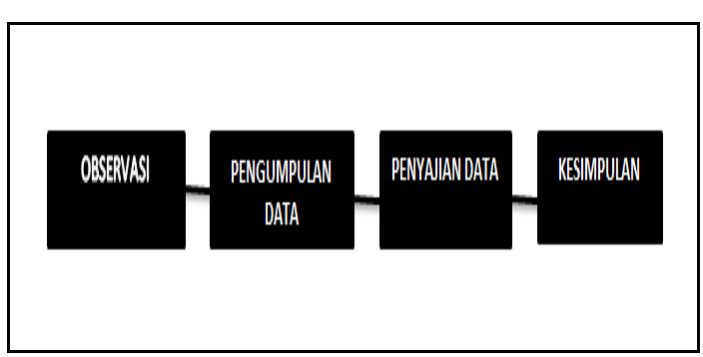

Gambar 1: Tahapan penyusunan penelitian

Penelitian ini dimulai dari sebuah observasi yang telah dilakukan jauh-jauh hari untuk mengetahui perilaku mahasiswa terhadap kemampuan menulisnya, selanjutnya terdapat tahapan penyusunan angket yang kemudian disebarluaskan kepada mahasiswa di UIN Sunan Kalijaga Yogyakarta melalui Google Form. Data-data yang diperoleh disusun sedemikian rupa dengan cara menarasikan beberapa data yang telah diperoleh dari penelitian kedalam bentuk tulisan yang didukung dengan beberapa refrensi untuk keabsahan artikel ini sehingga dari tulisan tersebut dapat menghasilkan sebuah kesimpulan.

\section{HASIL DAN PEMBAHASAN}

Menggalakkan budaya menulis sudah semestinya dilakukan sejak dini, terutama pada anak usia 7-11 tahun mengingat di perguruan tinggi sendiri membutuhkan mahasiswa yang kuat dalam penyampaian gagasan di bidang tulisan. Penelitian ini bertujuan meningkatkan budaya menulis yang tengah diambang pilu. Berdasarkan hasil pengamatan, setiap mahasiswa memliki beberapa cara tersendiri untuk mengungkapkan ide ataupun gagasannya di kelas. Ada kriteria mahasiswa yang sangat aktif berargumen namun tidak sedikit juga dari mereka yang terbilang pasif dalam hal berargumen. Baru-baru ini publikasi karya ilmiah menjadi hal yang wajib ditempuh oleh setiap mahasiswa di Perguruan Tinggi manapun, bahkan sejak semester pertamapun mahasiswa juga telah dikenalkan dengan dunia tulis menulis seperti pembuatan makalah.

Dampak rendahnya kemampuan menulis juga sangat dirasakan oleh mahasiswa, mengingat tugas-tugas yang diberikan di bangku perkuliahan tidak sedikit mewajibkan mahasiswanya untuk membuat sebuah karya tulis seperti makalah, artikel, skripsi, tesis dan disertasi. Pada awal perkuliahan sangat berat dirasakan, bahkan dengan segansegan mereka rela mengabaikan tugas- 


\begin{tabular}{|c|c|c|} 
Kredo 4 (2020) \\
KREDO: Jurnal Ilmiah Bahasa dan Sastra \\
Terakreditasi Sinta 4 berdasarkan Keputusan Direktorat \\
Jenderal Penguatan Riset dan Pengembangan, \\
Kementerian Riset, Teknologi dan Pendidikan Tinggi \\
Republik Indonesia \\
Nomor: 23/E/KPT/2019. 08 Agustus 2019 \\
https://jurnal.umk.ac.id/index.php/kredo/index
\end{tabular}

tugas tersebut dengan men-copy paste sebuah tulisan dari berbagai sumber demi memenuhi tugas yang diberikan oleh dosen. Padahal mereka cukup berwawasan dalam menyampaikan gagasan ketika berpresentasi, namun karena minimnya kemampuan menulis mereka terbilang cukup kesulitan dalam menuangkan gagasan tersebut kedalam bentuk tulisan dan lebih memilih jalan yang instan dengan mencopy-paste karya orang lain.

Sebab adanya rendahnya kempuan menulis bersumber pada minat baca yang rendah, padahal semakin banyak membaca maka semakin banyak pula gagasan yang kita punya itu bisa dijadikan sebagai mengembangkan tulisan. Berdasarkan hasil survey United Nations Educational Scientific and Cultural Organization (UNESCO) pada tahun 2012 dinyatakan bahwa minat masyarakat Indonesia dalam membaca baru mencapai angka 0,001. Artinya dari setiap 1.000 orang Indonesia hanya ada 1 orang saja yang memiliki minat baca.

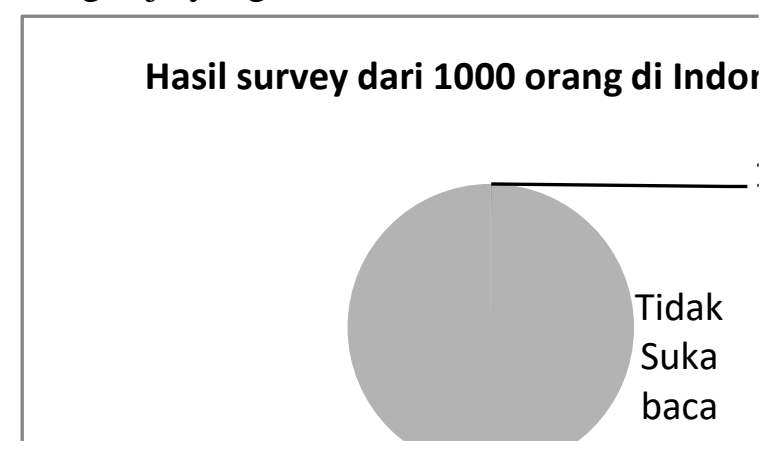

Gambar 2: Hasil survey UNESCO tahun 2012

Berdasarkan hasil survey pada bagan diatas dapat kita ketahui bersama bahwa budaya membaca di Negara ini rendah bahkan dapat dikatakan rendah sekali. Padahal membaca bertujuan untuk memperoleh informasi, dari kegiatan tersebut beberapa ilmu akan kita peroleh sehinga terbukalah cakrawala ilmu yang kita miliki. Pendidikan sangat erat kaitannya dengan budaya membaca, bahkan pada UU No 20 tahun 2003 Bab III/Pasal 4 dijelaskan bahwa pendidikan itu sendiri dilaksanakan dengan mengembangkan budaya membaca, menulis dan berhitung. Hasil dari penelitian ini juga berhasil mengungkap dari beberapa penjelasan mahasiswa yang diperoleh dari Google Form bahwasannya budaya membaca merupakan salah satu cara untuk mencapai tujuan dari pendidikan itu sendiri mengingat devinisi pendidikan menurut Hari Santoso (2015) adalah usaha sadar yang di pikirankan secara terencana oleh sebuah sistem yang memiliki cita-cita untuk mewujudkan suasana belajar dan proses pembelajaran agar siswa sendiri dapat secara aktif untuk mengembangkan potensi diri berdasarkan dengan beberapa kriteria tertentu seperti untuk memilki kekuatan spiritual agama, akhlaq mulia, kecerdasan dan keterampilan yang berguna untuk masyarakat, bangsa dan Negara. Berdasarkan devinisi pendidikan tersebut dapat kita tarik kesimpulan bahwa untuk mencapai tujuan pendidikan sendiri adalah dengan cara menggiatkan budaya membaca pada peserta didik, dengan begitu perlahan budaya menulis juga akan beriringan dengan budaya membaca itu sendiri.

Selain itu, hasil survey yang dilakukan oleh PISA juga menunjukkan bahwa Indonesia menempati peringkat 64 dari 65 negara dalam hal budaya literasi. Budaya Literasi memiliki peran 


Kredo 4 (2020)
KREDO: Jurnal Ilmiah Bahasa dan Sastra
Terakreditasi Sinta 4 berdasarkan Keputusan Direktorat
Jenderal Penguatan Riset dan Pengembangan,
Kementerian Riset, Teknologi dan Pendidikan Tinggi
Republik Indonesia
Nomor: 23/E/KPT/2019. 08 Agustus 2019
https://jurnal.umk.ac.id/index.php/kredo/index

penting dalam perkembangan suatu bangsa, kita bisa melihat dari kebiasaan orang Jepang dalam menghabiskan waktu senggangnya untuk membaca sehingga Negara tersebut dikenal dengan Negara maju teutama dalam hal industi. Kondisi real yang menjadi hasil dari sebuah survey merupakan tolak ukur bahkan menjadi pekerjaan rumah yang belum terpecahkan untuk kita semua, karena jika kita melihat beberapa Negara maju di dunia ini semua kemajuannya itu berawala dari kegiatan membaca. Octavia Muning Syekti (2015:221)

Budaya literasi dalam hal tulismenulis juga demikian, rendahnya budaya membaca berdampak pada minimnya budaya menulis. Padahal, kebiasaan membaca akan berjalan lurus dengan kemampuan menulis karena dengan membaca seseorang akan memperoleh kosakata serta menyusun bahkan mengembangkan ide untuk membuat tulisan yang lebih terstruktur dan lebih bermakna lagi. Upaya menggiatkan minat membaca pada anak usia Sekolah Dasar tentunya harus didukung oleh berbagai pihak terutama guru dan orang tua. Guru dan orang tua memiliki peran yang cukup besar karena kedua pihak ini memiliki kedekatan emosional yang paling dekat dengan si anak. Orang tua haruslah membimbing anaknya untuk melakukan kegiatan membaca sejak dini di rumah, sedangkan guru turut serta berpartisipasi aktif dalam menggiatkan minat baca di sekolah

\section{Eskalasi Budaya Menulis}

Komunikasi merupakan salah satu proses dalam menyampaikan pesan kepada penerima, baik itu melalui lisan ataupun tulisan. Menulis pada dasarnya merupakan keterampilan untuk berkomunikasi secara tidak langsung yang didalamnya terdapat suatu proses penuangan pikiran, ide kratif dan perasaan yang dituangkan kedalam bentuk tulis untuk dinikmati dan dimengerti orang lain.

Keterampilan menulis sendiri pada dasarnya dapat dilatih, namun ia juga dapat dipengaruhi bahkan membutuhkan kerjasama antara kegiatan membaca dan menyimak karena kedua kegiatan ini saling berkesinambungan dan berkaitan untuk menunjang kesempurnaan sebuah tulisan.

Membaca juga dapat meningkatkan kualitas sebuah tulisan, meskipun keduanya memang berbeda namun adanya kegiatan membaca mampu dengan mudah menyimak sebuah informasi dan kualitas bacaannya terbilang bagus, dengan begitu si penulis akan banyak memiliki pengalaman dan pengetahuan bacaan yang lebih banyak, sehingga kualitas tulisan mengikuti dengan apa yang ia baca.

Seseorang dapat menyampaikan pesan, maksud, gagasan ataupun pikiran kepada orang lain tanpa harus bertemu ataupun bertatap muka secara langsung. Menulis sendiri menggunakan tanda konvensional yang dapat dibaca untuk mencapai tujuannya namun juga tidak melupakan unsur-unsur terpenting lainnya seperti penulis, makna yang ingin disampaikan, bahasa yang digunakan dalam sistematika penulisan, pembaca, tujuan atau sesuatu yang ingin disampaikan kepada pembaca dan beberapa interaksi yang terjadi antara penulis dan pembaca melalui sebuah tulisan. 


\begin{tabular}{|c|c|c|} 
Kredo 4 (2020) \\
KREDO: Jurnal Ilmiah Bahasa dan Sastra \\
Terakreditasi Sinta 4 berdasarkan Keputusan Direktorat \\
Jenderal Penguatan Riset dan Pengembangan, \\
Kementerian Riset, Teknologi dan Pendidikan Tinggi \\
Republik Indonesia \\
Nomor: 23/E/KPT/2019. 08 Agustus 2019 \\
https://jurnal.umk.ac.id/index.php/kredo/index
\end{tabular}

Proses dalam pembuatan tulisan tidaklah mudah, tidak seperti membalikkan telapak tangan yang secara cepat dan tanpa perlu banyak berfikir. Tujuan tersampaikannya pesan harus digencarkan agar tidak terjadi perbedaan pesan antara penulis dan pembaca, oleh sebab itu diperlukannya sebuah keterampilan khusus agar menjadi penulis yang professional dan komunikatif.

\section{Urgensi Budaya Menulis}

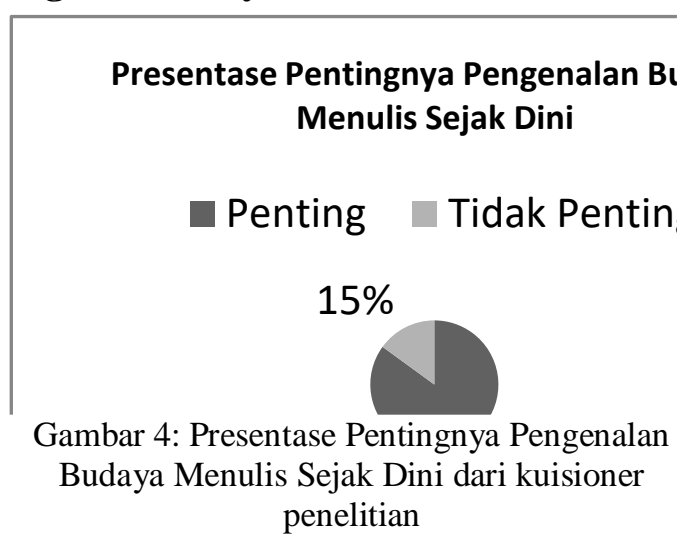

Grafik diatas merupakan grafik yang diperoleh dari responden yang mengisi kuisioner. Dari situ kita bisa menilai bahwa sebagian besar responden mengaku bahwa pentingnya eskalasi budaya menulis sejak dini sudah harus dilakukan. Beberapa responden menilai bahwa budaya menulis sejak dini merupakan suatu hal yang penting dilakukan mengingat sesuatu yang dilakukan sejak jauh hari akan menghasilkan hasil yang maksimal karena mereka telah matang dalam melakukan sebuah persiapan. Beberapa mahasiswa yang saya temui juga mengakui bahwa budaya menulis memang harus dikenalkan sejak sekolah dasar karena akan terasa penting sekali 92 Jurnal Kredo Vol. 4 No. 1 Oktober 2020 memiliki kemampuan menulis terutama dalam menunjang dunia pendidikan di perguruan tinggi.

Menulis menjadi sesuatu yang sangat berguna bagi masa depan seseorang karena dengan menulis tidak akan hilang dalam peradapan dunia, dengan begitu jejak langkah yang pernah terjadi dapat ditelusuri pada masa yang akan datang.

Berikut beberapa opini dari responden yang terekam dari kuisioner yang penulis sebarkan guna mendukung penelitian eskalasi budaya menulis sejak usia 7-11 tahun:

1. "Menulis penting karena menulis merupakan kemampuan dasar manusia. Dengan menulis, manusia dapat memberikan informasi secara terarah dan sistematis. Dengan begitu, manusia dapat memberikan manfaat dengan tulisannya kepada manusia yang membaca tulisannya"

2. "Karena jika tidak dibudayakan dari kecil maka saat dewasa akan jadi seperti saya ini. Malas menulis, tidak memiliki ide, dan sering blank"

3. "Saya saja yang dilatih menulis sejak kecil sering mengalami kesulitan, apalagi jika tidak dilatih sejak kecil, pasti akan lebih susah untuk mengembangkan keterampilan menulisnya. Dengan menulis siswa dapat membuat karya dan bisa mengekspresikan dirinya dengan tulisan"

4. Karena dengan menulis, dapat membiasakannya untuk suka membaca, melatih kreatifitas, dan mengungkapkan perasaannya melalui tulisan 


Kredo 4 (2020)
KREDO: Jurnal Ilmiah Bahasa dan Sastra
Terakreditasi Sinta 4 berdasarkan Keputusan Direktorat
Jenderal Penguatan Riset dan Pengembangan,
Kementerian Riset, Teknologi dan Pendidikan Tinggi
Republik Indonesia
Nomor: 23/E/KPT/2019. 08 Agustus 2019
https://jurnal.umk.ac.id/index.php/kredo/index

5. Dengan menulis, pengetahuan akan mulai terurai serta melatih menyampaikan ide/gagasan

Beberapa argument tersebut dapat diambil kesimpulan secara garis besar yaitu budaya menulis dinilai penting dengan menimbang daya ingat manusia yang terbatas jadi memang sudah seharusnya jika tidak ingin melupakan peristiwa/bab yang tidak ingin dilupakan pada masa lampau. Selain itu, menulis sejak dini juga dirasa penting terutama dalam meningkatkan kemampuan menulis, karena untuk dapat menyusun tulisan yang mudah dipahami dan terstruktur memang perlu dilatih jauhjauh hari. Hal itu dapat digambarkan dengan gambar bagan dibawah ini yang menerangkan bahwa budaya pengenalan menulis memang sudah selayaknya dikenalkan sejak jauh-jauh hari terutama sejak usia 7-11 tahun.

\section{Fiksi untuk Anak Sekolah Dasar}

Kemampuan menulis sejatinya dapat dilatih setiap hari, untuk membiasakan budaya tersebut juga harus sudah dikenalkan sejak sekolah dasar. Permasalahan yang kerap terjadi saat ini adalah masa anak-anak dalam menyukai hal-hal yang menyenangkan seperti bermain, menonton televisi bahkan bermain handphone. Disinilah peran pendidik dalam mensiasati permasalahan tersebut karena jika dibiarkan akan berpengaruh terhadap masa depan anak. Salah satu cara untuk mensiasati problematika tersebut adalah dengan mengenalkan pada mereka tentang sastra anak terutama fiksi.

Sastra anak terbilang sesuatu hal yang menyenangkan, imajinasi akan terdorong untuk berkhayal tentang dunia fantasi disaat itulah seorang pendidik memiliki peluang untuk mendorong mereka dalam mengungkapkan apa yang ada di dalam pikirannya terutama dengan menggunakan media tulis-menulis, dengan begitu anak-anak akan mulai terbiasa dengan dunia literasi.

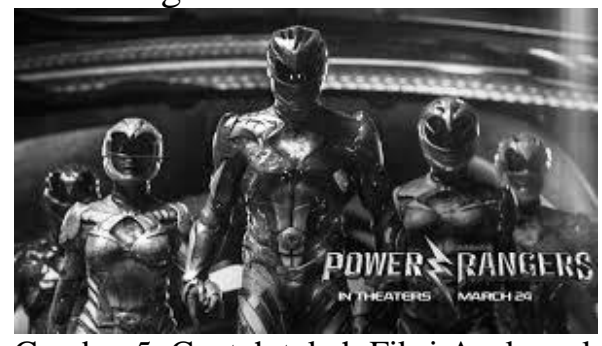

Gambar 5: Contoh tokoh Fiksi Anak-anak

Secara emosional psikologis sastra anak akan mudah dipahami mengingat usia yang cocok dan pola pikir imajinatif yang dapat kita lihat dalam kehidupan sehari-hari. Anak-anak cenderung akan berimajinasi ketika dikenalkan tentang sebuah karangan fiktif seperti berkhayal menjadi Power Rangers, Putri Salju, Spideman dan tokoh-tokoh fiktif lainnya karena sastra anak merupakan dunia rekaan hasil imajinasi yang menghadirkan keindahan tertentu bagi penikmatnya.

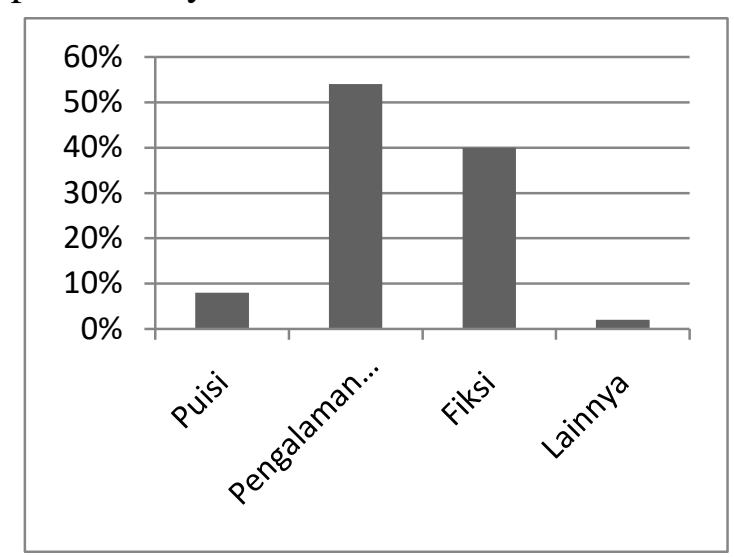

Gambar 6: Presentase jenis sastra yang cocok diterapkan pada anak usia Sekolah Dasar menurut responden pada kuisioner penelitian 


Kredo 4 (2020)
KREDO: Jurnal Ilmiah Bahasa dan Sastra
Terakreditasi Sinta 4 berdasarkan Keputusan Direktorat
Jenderal Penguatan Riset dan Pengembangan,
Kementerian Riset, Teknologi dan Pendidikan Tinggi
Republik Indonesia
Nomor: 23/E/KPT/2019. 08 Agustus 2019
https://jurnal.umk.ac.id/index.php/kredo/index

Sastra yang dikenalkan sejak sekolah dasar bermacam-macam, mulai dari jenis karangan fantasi/fiksi, nonfiksi, puisi bahkan sampai sastra tradisional seperti fable, dongeng, legenda dan epos. Pada gambar 6 mahasiswa berpendapat bahwa ada beberapa jenis tulisan yang sangat direkomendasikan untuk diterapkan pada anak-anak sekolah dasar seperti menulis pengalaman pribadi, fiksi, puisi dan lainlain. Hasil dari penelitian mengungkap bahwa menulis pengalaman pribadi menjadi pokok bahasan yang paling disukai anak-anak, disusul menulis cerita fiksi yang menjadi juara ke-dua. Penulis menyadari bahwa ternyata menulis pengalaman pribadi juga penting untuk dikenalkan pada anak sekolah dasar, pada dasarnya menulis pengalaman pribadi juga merupakan wujud pengabadian diri dengan begitu memori yang telah terjadi dimasa lampau dapat diingat dimasa kini.

Anak-anak merupakan masa yang bagus dalam perkembangan otak, oleh karena itu inilah waktu yang tepat untuk mengenalkan dunia tulis menulis. Salah satu metode dalam memperkenalkan dunia tersebut adalah dengan memberikan beberapa buku/bacaan yang sesuai dengan tahap perkembangannya. Dengan begitu anak akan mendapat beberpa reverensi bahkan angan-angan untuk menulis dan mengembangkan bacaan berdasarkan pengalaman membacanya.

Menulis cerita pengalaman pribadi sejatinya juga dapat dikembangkan dalam dunia tulis menulis, mengingat disatu sisi usia anak memiliki daya imajinasi yang cukup bagus dalam berkhayal maka seorang pendidik dapat memanfaatkan momentum tersebut dengan me-remix sebuah cerita pengalaman pribadi dengan fiksi. Misalnya seorang anak sedang bermain bola di halaman rumah, maka anak bisa diminta untuk merekayasa apa yang telah mereka lakukan didunia nyata dengan suasana fantasi seperti cerita pada Madun atau Kapten Tsubasai dengan begitu terciptalah sebuah karangan fiksi bertajuk pengalaman pribadi yang mengesankan. Hal itu tentunya selaras dengan teori penjelasan fiksi yang menerangkan bahwa karangan ini bersifat imajinatif, artinya sesuatu yang ditulis bersumber pada khayalan dari penulisnya. Meskipun begitu, karya ini tetap dilandasi dengan kesadaran dan tanggung jawab dari segi kreatifitas sebagai karya seni yang berestetika untuk menemukan karangan/produk baru yang tidak biasa ditemukan didalam kehidupan.

\section{SIMPULAN}

Dunia perkuliahan erat kaitannya dengan dunia tulis, mengingat disetiap semester pasti seorang dosen memberikan tugas dalam bentuk tulisan seperti membuat makalah ataupun artikel serta munculnya surat edaran dari lembaga pendidiakan di Indonesia tentang standar pendidikan di Perguruan Tinggi yang mewajibkan setiap mahasiswa untuk mempublikasi karya ilmiah seperti skripsi, tesis dan distertasi. Hal itu membuat mahasiswa mau ataupun tidak harus mulai berlajar menulis sejak jauh-jauh hari jika ingin menghasilkan tulisan yang berkualitas, berbobot dan informatif. Dalam penerapannya tidak sedikit mahasiswa

\section{4 | Jurnal Kredo}

Vol. 4 No. 1 Oktober 2020 


\begin{tabular}{|c|c|c|} 
Kredo 4 (2020) \\
KREDO: Jurnal Ilmiah Bahasa dan Sastra \\
Terakreditasi Sinta 4 berdasarkan Keputusan Direktorat \\
Jenderal Penguatan Riset dan Pengembangan, \\
Kementerian Riset, Teknologi dan Pendidikan Tinggi \\
Republik Indonesia \\
Nomor: 23/E/KPT/2019. 08 Agustus 2019 \\
https://jurnal.umk.ac.id/index.php/kredo/index
\end{tabular}

yang mengaku kesulitan dalam menulis, beberapa kesulitan tersebut berupa minimnya ide yang dimiliki sehingga dalam proses menulisnya pun sering merasa blank atau bisa disebut dengan tidak tau apa yang akan ditulis, selain itu banyak responden yang mengaku malas dalam menulis dan minimnya minat baca juga menjadi sebab seseorang tidak tau menahu dalam hal menulis karangan ataupun artikel. Peran penting eskalasi budaya menulis fiksi pada anak usia 12 tahun adalah dapat menghadirkan generasi emas selanjutnya yang tidak hanya pandai dalam menyampaikan gagasannya melalui lisan akan tetapi juga dapat mengungkapkannya melalui media lain yang disebut tulisan.

Hasil penelitian mengungkap bahwa menulis cerita pengalaman pribadi dan menulis cerita fiksi merupakan bentuk karangan yang cocok untuk dikenalkan pada anak sekolah dasar. Menulis sendiri menjadi budaya yang sangat penting selain merupakan skill yang wajib dimiliki oleh mahasiswa, menulis juga merupakan bentuk pengabadian diri dari sejarah atas minimnya daya ingat yang dimiliki oleh manusia. Menulis fiksi sendiri pada dasarnya juga sesuai dengan pola pikir anak-anak pada umumnya, mengingat daya imajinatif yang mereka miliki cukup baik disinilah peran penting karangan fiksi perlu dimasukkan kedalam dunia tulis menulis. Harapan adanya budaya menulis juga tidak terletak pada keterampilan seseorang dalam menulis saja, namun juga mematahkan dunia literasi yang tengah merosot dipasaran terutama pada sastra anak sendiri yang terbilang langka ditemukan.

\section{DAFTAR PUSTAKA}

Aghittara, Amanda Oksaventa. 2016. "Peningkatan Keterampilan Menulis Cerita Fiksi Melalui Metode Eksplorasi Membaca Siswa Kelas IV." BASIC EDUCATION 5 (30): 2-831.

Amar, Raichul. 2018. "MENINGKATKAN BUDAYA MENULIS BAGI PENULIS MUDA: Beberapa Catatan Terhadap Sebuah Kursus Kepenulisan." Shaut AlMaktabah: Jurnal Perpustakaan, Arsip Dan Dokumentasi 10 (2): 201-10.

Caroline, Apriyani, and Nova Yohana. 2018. "Komunikasi Persuasif Komunitas Kongkow Nulis Dalam Meningkatkan Budaya Menulis Di Kalangan Mahasiswa Kota Pekanbaru." Riau University.

Faidah, Citra Nur. 2018. "Dekonstruksi Sastra Anak: Mengubah Paradigma Kekerasan Dan Seksualitas Pada Karya Sastra Anak Indonesia." KREDO: Jurnal Ilmiah Bahasa Dan Sastra 2 (1): 126-39.

Nurmayani, Eva, and Hilmiyatun Hilmiyatun. 2018. "Hubungan Pengetahuan Tentang Sastra Dan Minat Membaca Karya Sastra Dengan Kemampuan Mengapresiasi 


Kredo 4 (2020)
KREDO: Jurnal Ilmiah Bahasa dan Sastra
Terakreditasi Sinta 4 berdasarkan Keputusan Direktorat
Jenderal Penguatan Riset dan Pengembangan,
Kementerian Riset, Teknologi dan Pendidikan Tinggi
Republik Indonesia
Nomor: 23/E/KPT/2019. 08 Agustus 2019
https://jurnal.umk.ac.id/index.php/kredo/index

Karya Sastra (Studi Korelasi Pada Mahasiswa FKIP (Luar Jurusan PBS) Universitas Hamzanwadi." In Prosiding Seminar Nasional Lembaga Penelitian Dan Pendidikan (LPP) Mandala, 187-95.

Santoso, Hari. 2015. "Upaya Meningkatkan Minat Dan Budaya Membaca Buku Melalui Iklan Layanan Masyarakat.” Library. Um. Ac. Id,(1), 1-19.

Sayekti, Octavian Muning. 2015. "Sastra Anak Untuk Membangun Budaya Literasi." Trihayu 2 (1).

Sukmadinata, S N. 2005. "Metode Penelitia." Bandung: PT Remaja Rosdakarya.

Winarsih, Eni, and Rahayu Sulistyowati. 2016. "PENERAPAN PENDEKATAN SAINTIFIK DALAM MATA KULIAH UMUM (MKU) BAHASA INDONESIA UNTUK MENUMBUHKAN BUDAYA MENULIS MAHASISWA IKIP PGRI MADIUN." Widyabastra: Jurnal Ilmiah Pembelajaran Bahasa Dan Sastra Indonesia 4 (2): 141-57. 